\title{
HUBUNGAN ANTARA KEPEMIMPINAN PEMBELAJARAN KEPALA SEKOLAH, KOMPETENSI PEDAGOGIK GURU PAI DAN KARAKTER RELIGIUS-TOLERAN SISWA MUSLIM DI SEKOLAH MULTIKULTURAL
}

\author{
Aan Fardani Ubaidillah ${ }^{1}$, Ibrahim Bafadal ${ }^{2}$, Nurul Ulfatin ${ }^{3}$, \&Achmad Supriyanto $^{4}$ \\ Fakultas Ilmu Pendidikan, Universitas Negeri Malang 1, 2, 3, \& 4 \\ email:afubaidillah@gmail.com ${ }^{1}$,ibrahim.bafadal.fip@um.ac.id ${ }^{2}$,nurul.ulfatin.fip@um.ac.id ${ }^{3}, \&$ \\ a.supriyanto.fip@um.ac.id ${ }^{4}$
}

\begin{abstract}
Abstrak
Penelitian ini bertujuan untuk menjelaskan hubungan antara kepemimpinan pembelajaran kepala sekolah, kompetensi pedagogik guru Pendidikan Agama Islam (PAI) dan karakter religius-toleran siswa muslimdi sekolah multikultural. Penelitian ini menggunakan pendekatan kuantitatif dengan metode penelitian deskriptifkorelasional. instrumen penelitian menggunakan angket yang disebarkan kepada guru dan siswa pada sampel terpilih. Hasil penelitian menunjukan bahwa, baik secara parsial maupun secara simultan, kepemimpinan pembelajaran kepala sekolah berpengaruh terhadap karakter religius-toleran siswa muslim. Secara tidak langsung variabel kepemimpinan pembelajaran tidak memiliki pengaruh terhadap karakter religius-toleran siswa muslim melalui variabel kompetensi pedagogik guru PAI.
\end{abstract}

Kata kunci: Kepemimpinan Pembelajaran, Kompetensi Pedagogik, Karakter Religius-Toleran, Sekolah Multikultural

\begin{abstract}
This study aims to explain the relationship between instructional leadershipof the School Principal's, pedagogical competence of Islamic Religius Education (PAI) teachers and religius-tolerantcharacter of muslim students in multicultural schools. This research uses quantitative with descriptive-correlational research methods. The research instrument used a questionnaire distributed to teachers and students in selected samples. The results showed, both partially and simultaneously, the instructionalleadership of the school principal's towards the religius-tolerantcharacter of muslim students. indirectly, the instructional leadership variabel has no influence on the religius-tolerant character of muslim students through pedagogical competency of the PAI's teacher variabel.
\end{abstract}

Keywords: Instructional Leadership; Pedagogical Competence; Religius-Tolerant Character; Multicultural School

\section{PENDAHULUAN}

Pada

dasarnya

pengembanganinstitusi pendidikan selalu

berkaitan dengan 3 hal, antara lain: 1) Harapan (what), 2) Tugas (which), 3) cara pelaksanaan (how). Poin pertama (what) berkaitan hal-hal yang paling pokok dalam pengelolaan pendidikan, yaitu terkait landasan dan tujuan pendidikan. Poin kedua (which) berkaitan dengan kebijakan yang diambil dalam rangkai mencapai tujuan pendidikan. Dan poin ketiga (how) berkaitan dengan metode yang dipergunakan dalam implementasi 
kebijakan yang telah diambil (Kasmiran, 1981:63).

Dari pandangan di atas, maka proses pengembangan lembaga pendidikan akan membutuhkan seorang leader sebagai pemegang tanggung jawab utama,yang dalam pelaksanaannya disebut sebagai kepala sekolah. Kepala sekolah pada dasarnya merupakan guru yang mendapat tugas tambahan sebagai kepala sekolah (Sudarman 2002: 145). Pemilihan sosok kepala sekolah sendiri harus sejalan dengan Peraturan Menteri Pendidikan Nasional no. 13 tahun 2007 tentang standar kepala sekolah. Standar kompetensi yang harus dimiliki kepala sekolah ada 5 macam, yaitu: (1) kompetensi kepribadian, (2) kompetensi manajerial, (3) kompetensi kewirausahaan, (4) kompetensi supervisi, (5) kompetensi sosial.

Berdasarkan kompetensi tersebut maka tugas kepala sekolah sebagai seorang manajer sebuah lembaga pendidikan tentunya sangat kompleks, tidak sekedar mengelola kurikulum pembelajaran, tenaga kependidikan dan non kependidikan, tetapi juga mengelola keuangan serta mengembangkan aset lembaga. Untuk melaksanakan tugas ini maka seorang kepala sekolah harus memiliki tiga kecerdasan, yakni kecerdasan profesional, kecerdasan personal dan kecerdasan manajerial (Dede Rosyada, 2013: 233). Kecerdasan profesional berkaitan dengan kemampuan seseorang dalam bidang tugasnya, yakni pendidikan. Seorang kepala sekolah idealnya memiliki kompetensi yang baik terkait teknik penyusunan kurikulum sekolah, perencanaan pembelajaran, pemilihan strategi pembelajaran, pelaksanaan evaluasi pembelajaran, pengelolaan kelas, dan lain-lain.

Bersamaan dengan itu, kepala sekolah perlu memiliki kecerdasan personal, yaitukemampuan dalam menerima dan menghargai orang lain. Kepala sekolah dituntut untuk menghargai guru, tenaga kependidikan, orang tua siswa dan bahkan tokoh-tokoh pendidikan di sekitar sekolah. Terakhir, figur kepala sekolah harus memiliki kecerdasan manajerial, yakni memiliki visi misi yang besar dalam memajukan lembaganya, mampu mengorganisir seluruh stafnya untuk melaksanakan program yang sudah ditetapkan, mampu memotivasi seluruh staf akademik dan staf non akademik, dan selalu menghargai kinerja stafnya tersebut.

Sebagai tokoh nomor satu dalam sebuah satuan pendidikan, Kepala sekolah memiliki peran sentral dalam penentuan mutu dan kemajuan sebuah lembaga pendidikan. Kemajuan besar dalam sebuah lembaga pendidikan hanya mungkin dicapai jika pengelolaan administrasi pendidikan dilaksanaan secara inovatif. Hal ini dikarenakan adminstrasi yang baik menduduki tempat yang sangat menentukan dalam struktur dan artikulasi sistem pendidikan (Sanusi, 2002: 132). Atas dasar inilah maka kemampuan manajerial kepala sekolah harus dipergunakan secara maksimal, efektif dan efisien. Kemampuan manajerial kepala sekolah dalam hal ini tentunya tidak hanya terkait tata kelola dan administrasi saja, tapi juga terkait pelaksanaan pendidikan di lembaga tersebut.

Dewasa ini, realitas yang terjadi di lapangan cukup memprihatinkan. Banyak kepala sekolah yang terjebak oleh rutinitas pekerjaan yang bersifat politis dan bersifat administratif semata (Sagala.2010:1). Bersifat politis diartikan bahwa kepala sekolah melakukan peran dan fungsinya terlalu mengacu kepada misi atau kepentingan politis sesaat para atasan atau pimpinan wilayah, yang tentunya hal ini akan berimbas pada dikesampingkannya kepentingan guru dan siswa yang seharusnya menjadi menjadi focus utama 
dalam peningkatan mutu pendidikan.Bersifat administratif, diartikan bahwa seorang kepala sekolah sering kali disibukkan dengan hal-hal yang bersifat administratif, sehingga upaya untuk menciptakan layanan prima bagi siswa dan upaya untuk menciptakan kondisi yang kondusif dalam proses belajar mengajar sedikit dikesampingkan. Untuk mengatasi hal ini, maka munculah konsep kepemimpinan pembelajaran.

Konsep kepemimpinan pembelajaran merupakan sebuah model kepemimpinan yang mengedepankan peningkatan kualitas akademik, bukan peningkatan kualitas sarana dan prasarana sekolah seperti gedung, fasilitas dan keuangan semata. Seluruh kesibukannya difokuskan untuk meningkatkan kualitas kegiatan akademik sekolah yang berkaitan dengan pembelajaran (Suhardan, 2010:73). Daresh \& Playcon mendefinisikan kepemimpinan pembelajaran sebagai upaya memimpin para guru agar melaksanakan proses belajar mengajar dengan baik, yang pada akhirnya dapat meningkatkan prestasi belajar siswa (Blasé \& Blasé, 2000:130).

Pendapat lain mendefinisikan kepemimpinan pembelajaran sebagai " to extent to which principal focus directly on teaching and learning, the importance of increasing student achievement, curriculum and assessment, and the development of improved instructional program" (Sergiovani, 2009:72).

Kemudian Petterson, menyimpulkan kepemimpinan pembelajaran yang efektif akan terjadi jika kepala sekolah melaksanakan beberapa hal berikut: (1) Kepala sekolah mensosialisasikan dan menginternalisasikan visi misi sekolahnya dengan baik. Dia juga mampu membangun keterbukaan dalam merumuskan visi dan misi sekolahnya, dan mampu menjaga agar visi dan misi sekolah dapat tumbuh subur dalam implementasinya; (2) Kepala sekolah melibatkan stake holder dalam pengelolaan sekolah (manajemen partisipatif). Pelibatan stakeholder ini dalam pengambilan keputusan dan dalam kegiatan operasional sekolah sesuai dengan kemampuan dan batas-batas peraturan yang berlaku; (3) Kepala sekolah memberikan dukungan terhadap peningkatan kualitas pelaksanakan pembelajaran, (4) Kepala sekolah melakukan monitoring terhadap proses belajar mengajar; (5) Kepala sekolah berperan sebagai fasilitator pembelajaran sehingga dengan berbagai cara dia dapat mengetahui kesulitan pembelajaran dan dapat membantu guru dalam mengatasi kesulitan pembelajaran yang terjadi di dalam kelas (Direktur Jenderal PMPTK, 2010:5).

Sejalan dengan beberapa definisi kepemimpinan pembelajaran di atas, Lunenburg \& Irby (2006:14) kemudian membagi karateristik kepemimpinan pembelajaran dalam lima aspek, yaitu: (1) fokus pembelajaran, (2) menumbuhkan kerjasama, (3) analisis hasil belajar siswa, (4) memberi bantuan akademik, (5) merancang kurikulum, pembelajaran, dan penilaian. Sedangkan Glickman (2002:7) membagi konsep kepemimpinan pembelajaran dalam tiga elemen penting, ketiga elemen tersebut tersaji pada Gambar 1:

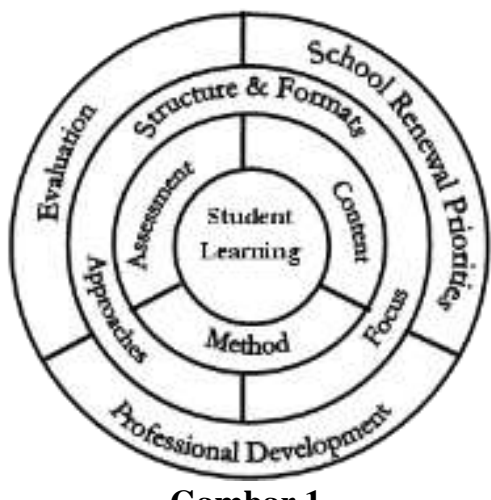

Gambar 1.

Tiga Elemen Kepemimpinan

Pembelajaran (Instructional Leadership) 
Berdasarkan gambar di atas, terdapat tiga elemen pokok dalam konsep kepemimpinan pembelajaran, yaitu: elemen yang berpengaruh terhadap pembelajaran secara langsung, elemen berhubungan dengan guru, dan elemen yang mendukung peningkatan hasil belajar. Dalam penyelenggaran sebuah lembaga pendidikan tiga elemen ini haruslah dilaksanakan secara utuh dan berkelanjutan. Dengan kata lain, ketiga elemen ini harus menjadi skala prioritas dalam pembuatan kebijakan dan layanan pembelajaran kepada siswa. Pembelajaran siswa akan mencapai hasil yang maksimal, jika proses belajar mengajar menjadi isu sentral dari seluruh manajemen sekolah dan seluruh aktifitas kepala sekolah (Lunenburg \& Irby, 2006:14).

Salah satu pihak penting yang terlibat dan berdampak langsung dalam proses penerapan kepemimpinan pembelajaran yang efektif adalah Guru. Kebijakan yang dikeluarkan kepala sekolah haruslah mendorong guru menjadi sosok guru yang professional. untuk menjadi guru yang professional seorang guru harus memiliki kompetensi yang mumpuni. Kompetensi merupakan pengetahuan, keterampilan, dan nilai-nilai dasar yang direfleksikan dalam kebiasaan berfikir dan bertindak. Dua kebiasaan jika dilakukan secara konsisten dan kontinyu dapat memungkinkan seseorang untuk menjadi pribadi yang kompeten, dalam arti memiliki pengetahuan, keterampilan dan nilai-nilai dasar untuk melakukan sesuatu secara baik dan benar (Akhyak, 2005:19).

Kompetensi guru itu sendiri didefinisikan sebagai perpaduan antara kemampuan personal, keilmuan, teknologi, sosial dan spiritual yang secara sempurna membentuk kompetensi standar profesi guru. Kompetensi Guru ini yang mencangkup penguasaan materi yang diajarkan, pemahaman terhadap siswa, pembelajaran yang berkualitas, pengembangan personality dan profesionalisme (Mulyasa, 2007: 26). Kompetensi guru juga dapat diartikan sebagai pengetahuan, keterampilan dan kemampuan yang dikuasai oleh seseorang yang menjadi bagian dari dirinya sehingga ia dapat melakukan perilaku tertentu dengan sebaik-baiknya. Sedangkan menurut pendapat lain, kompetensi guru didefinisikan sebagai seperangkat penguasaan, kemampuan yang harus ada dalam diri guru agar dapat mewujudkan kinerjanya secara efektif dan efisien (Kunandar, 2007:55).

Agar kompetensi guru dapat terwujud maka haruslah ada kesadaran untuk berkompetensi. Kesadaran akan kompetensi menuntut tanggungjawab guru untuk berani menghadapi tantangan dalam melaksanakan tugas maupun berinteraksi dengan lingkungannya. Untuk itu Guru juga harus berani merubah dan menyempurnakan diri sesuai dengan tuntutan zaman. Dalam Undang-Undang Nomor No. 14tahun 2005 tentang Guru dan Dosen dan Peraturan Pemerintah No. 19 tahun 2005 tentang Standar Nasional Pendidikan, dinyatakan bahwa kompetensi guru meliputi kompetensi kepribadian, pedagogik, professional, dan sosial (Sarimaya, 2008:17). Dari keempat kompetensi tersebut, kompetensi pedagogik merupakan kompetensi utama yang harus dimiliki seorang guru, karena kompetensi ini berkaitan erat dengan kualitas pembelajaran. Kompetensi pedagogik dalam Standar Nasional Pendidikan pasal 26 ayat 3 butir a didefinisikan sebagai kemampuan mengelola pembelajaran siswa yang meliputi pemahaman terhadap siswa, perencanaan dan pelaksanaan pembelajaran, evaluasi hasil belajar, dan pengembangan siswa untuk mengaktualisasikan berbagai potensi yang dimilikinya (Sarimaya, 2008:75). 
Secara rinci setiap sub-kompetensi kompetensi pedagogikdijabarkan sebagai berikut:

1. Memahami karakteristik siswa secara mendalam, dengan indikator esensial: memahami karakteristik siswa dengan memanfaatkan prinsip-prinsip perkembangan kognitif, memahami siswa dengan memanfaatkan prinsip-prinsip kepribadian, dan mengidentifikasi bekal awal siswa.

2. Merancang pembelajaran, termasuk memahami landasan pendidikan. Sub kompetensi ini memiliki indikator esensial: memahami landasan pendidikan, menerapkan teori belajar dan pembelajaran, menentukan strategi pembelajaran berdasarkan karakteristik siswa, kompetensi dasar dan materi ajar, serta menyusun Rencana Pelaksanaan Pembelajaran (RPP) berdasarkan strategi pembelajaran yang dipilih.

3. Melaksanakan pembelajaran dengan indikator esensial: menata latar (setting) pembelajaran, dan melaksanakan pembelajaran secara kondusif.

4. Merancang dan melaksanakan evaluasi pembelajaran memiliki indikator esensial: merancang dan melaksanakan evaluasi (asessement) proses dan hasil belajar dengan menentukan tingkat ketuntasan belajar (KKM), dan memanfaatkan hasil penilaian pembelajaran untuk perbaikan kualitas program pembelajaran selanjutnya.

5. Mendorong siswa untuk daoat mengaktualisasikan berbagai kompetensinya, dengan indikator esensial: memfasilitasi siswa untuk mengembangkan berbagai potensi akademik dan potensi non akademik (Sarimaya, 2008:19-20).
Penjelasan ini mempertegas bahwa guru dengan kompetensi pedagogik yang dimilikinya memiliki peran yang sangat sentral dalam sebuah proses pendidikan. Apapun yang disampaikan dan dilaksanakan guru di kelas secara langsung akan ikut serta dalam mempengaruhi pembentukan pengetahuan dan karakter siswa. Istilah karakter dihubungkan dan dipertukarkan dengan istilah etika, ahlak, dan atau nilai dan berkaitan dengan kekuatan moral, berkonotasi "positif" bukan netral. Oleh karena itu Pendidikan karakter secara lebih luas dapat diartikan sebagai pendidikan yang mengembangkan nilai budaya dan karakter bangsa pada diri siswa sehingga mereka memiliki nilai dan karakter sebagai karakter dirinya, menerapkan nilai-nilai tersebut dalam kehidupan dirinya sebagai anggota masyarakat, dan warga negara yang religius, nasionalis, produktif, dan kreatif.

Konsep terkait pendidikan karakter harus disikapi secara serius oleh seluruk pemangku kebijakan dan masyarakat, sebagai jawaban dari kondisi riil yang dihadapi bangsa Indonesia akhir-akhir ini yang ditandai dengan maraknyatindakan kriminalitas, memudarnya nasionalisme, munculnya rasisme, memudarnya toleransi beragama serta hilangnya religiusitas di masyarakat. Pengembangan dan penguatan karakter siswa menjadi isu penting dalam dunia pendidikan akhirakhir ini, hal ini berkaitan dengan fenomena banyaknya kasus intoleran yang dilakukan oknum-oknum tertentu di masyarakat dengan mengatasnamakan agama.

Kasus yang pernah mendera tanah air yang dilatarbelakangi oleh perbedaan SARA (suku, agama, ras, dan antar golongan) diantaranya adalah kasus Ambon dan Poso (konflik antar agama), peristiwa Sanggau Ledo, Sambas, dan Sampit (konflik antar etnis Dayak/Melayu 
dengan Madura) serta peristiwa Mei 1998 (konflik politik berimbas pada sentimen anti Cina), penyerangan jamaah Ahmadiyah di berbagai daerah di Indonesia seperti penyerangan jemaat Ahmadiyah di Cikeusik, Pandeglang, Banten, kerusuhan dan perusakan sejumlah gereja di Temangggung, Jawa Tengah, penyerangan terhadap pondok pesantren yang diduga beraliran Syiah di Pasuruan dan Sampang, Jawa Timur, teror "bom buku" ke sejumlah tokoh, "bom Jum'at" di Mapolres Cirebon, bom bunuh diri di Gereja Bethel Injil Sepenuh (GBIS) Solo, serta penembakan polisi di Solo dan Poso. Sederet aksi kekerasan tersebut membalikkan argumen toleransi masyarakat Indonesia. Bangsa yang dulu dikenal publik dunia dengan keramahan dan tingkat toleransi yang tinggi, tiba-tiba berubah seperti bangsa bar-bar yang tak beradab.

Karena hal tersebut di atas, kemudian persoalan kebangsaan dan upaya membangun kembali semangat toleransi tentunya cukup menjadi prioritas dalam membangun peradaban saat ini. Penanaman karakter religius-toleran melalui Pembelajaran Agama Islam harus dilakukan secara masif diberbagai level pendidikan. Pelaksanaan pendidikan karakter ini secara spesifik dilakukan agar nilai- nilai budaya bangsa yang telah memudar tersebut dapat kembali membudaya ditengah-tengah masyarakat. Berdasar pada kajian tersebut di atas, penelitian terkait hubungan antara kepemimpinan pembelajaran kepala sekolah, kompetensi pedagogik guru PAI dan karakter religius-toleran siswa muslim di sekolah multikultural sangat perlu untuk dilakukan.

Adapun, masalah penelitian yang hendak dijawab melalui penelitian ini dirumuskan sebagai berikut:

1. Bagaimana pengaruh kepemimpinan pembelajaran Kepala Sekolah terhadap karakter religius-toleran siswa muslim?,

2. Bagaimanapengaruh kompetensi pedagogik Guru Pendidikan Agama Islam terhadap karakter religiustoleran siswa muslim?,

3. Bagaimana pengaruh kepemimpinan pembelajaran dan kompetensi pedagogik guru Pendidikan Agama Islam terhadap karakter religiustoleran siswa muslim?, dan

4. Bagaimana pengaruh kepemimpinan pembelajaran terhadap karakter religius-toleran siswa muslim melalui kompetensi pedagogik guru Pendidikan Agama Islam?.

Bertolak dari keempat rumusan masalah penelitian, tujuan penelitian ini bermaksud menjelaskan pengaruh secara parsial antara: (1) kepemimpinan pembelajaran Kepala Sekolah terhadap karakter religius-toleran siswa muslim, dan (2) kompetensi pedagogik Guru Pendidikan Agama Islam terhadap karakter religius-toleran siswa muslim, menjelaskan pengaruh secara simultan antara kepemimpinan pembelajaran dan kompetensi pedagogik guru Pendidikan Agama Islam terhadap karakter religiustoleran siswa muslim, serta pengaruh kepemimpinan pembelajaran terhadap karakter religius-toleran siswa muslim melalui kompetensi pedagogik guru Pendidikan Agama Islam.

\section{METODE}

Penelitian ini dilakukan di SMAN 1 Sumbermanjing Wetan, Kabupaten Malang dengan menggunakan pendekatan kuantitatif berjenis korelasional. Responden penelitian adalah 23 orang guru dan 35 siswa kelas XI SMAN 1 Sumbermanjing Wetan. Data terkait kepemimpinan pembelajaran kepala sekolah diperoleh dari penilaian guru terhadap kepala sekolah, sedangkan data terkait kompetensi pedagogik guru PAI 
diperoleh dari siswa. Langkah ini diambil dengan asusmsi bahwa siswa lah yang mampu merasakan dan menilai secara langsung indicator kompetensi pedagogik guru PAI di kelas. Selain itu data terkait karakter religius-toleran didapatkan dari siswa secara langsung. Untuk mendapatkan informasi yang relevan, maka peneliti meminta responden untuk mengisi kuisioner yang berisi daftar pernyataan guna mendapatkan informasi tentang variabel-variabel yang diteliti.Instrument penelitian yang digunakan adalah 3 kuesioner, kuesioner yang pertama mengukur variabel kepemimpinan pembelajaran (x1), kuesioner yang kedua mengukur variabel kompetensi pedagogic guru PAI (x2) dan kuesioner yang ketiga mengukur variabel karakter religius-toleran siswa (y). Penelitian ini menggunakan skala Likert, yang terdiri dari lima pilihan jawaban atas pernyataan yang diajukan.

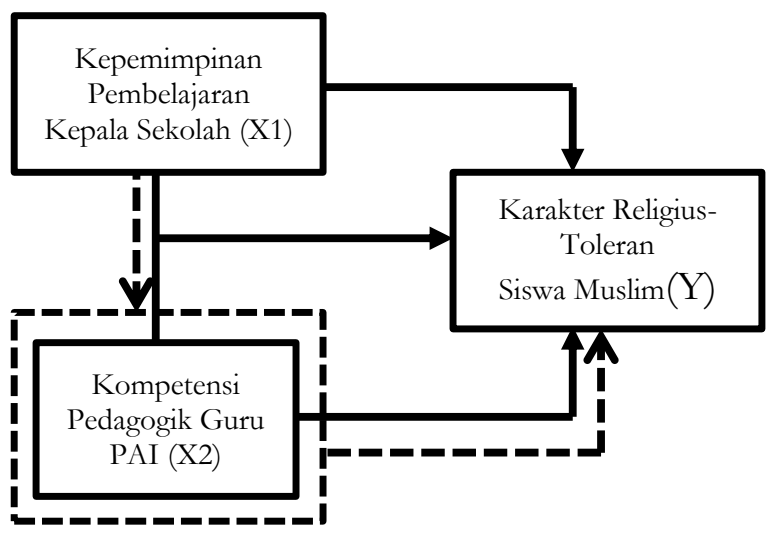

Gambar 2. Kerangka Berfikir

Hipotesis:

$\mathrm{X} 1$ berpengaruh terhadap Y secara parsial

$\mathrm{X} 2$ berpengaruh terhadap Y secara parsial

$\mathrm{X} 1$ dan X2 berpengaruh terhadap $\mathrm{Y}$ secara simultan
X1 berpengaruh terhadap Y melalui X2

Sebelum dilakukan pengumpulan data sebenarnya pada sampel terpilih, terlebih dahulu dilakukan pengujian validitas dan reliabilitas instrumen penelitian. Berdasarkan hasil analisis data, diketahui bahwa semua item soal yang digunakan untuk mengukur $\mathrm{X}_{1}, \mathrm{X}_{2}$ dan $\mathrm{Y}$ memiliki taraf signifikansi yang dibawah dari 0.05. Dari sini dapat disimpulkan bahwa semua item soal yang dalam penelitian ini adalah valid. Sedangkan hasil uji reliabilitas instrumen dalam penelitian ini dapat dilihat dalam tabel 1 :

Tabel 1. Uji Reliabilitas $X_{1}, X_{2}$ dan $Y$

\begin{tabular}{ccc}
\hline Variabel & Cronbach's Alpha & N of Items \\
\hline $\mathrm{X} 1$ & .604 & 5 \\
$\mathrm{X} 2$ & .786 & 5 \\
$\mathrm{Y}$ & .830 & 8 \\
\hline
\end{tabular}

Tabel 1 menunjukkan nilai Cronbach Alpha pada masing-masing variabel menunjukan angka di atas 0.6, hal ini berarti bahwa instrument penelitian yang digunakan memiliki tingkat kehandalan yang tinggi.

\section{HASIL}

\section{Analisis Data}

Pengolahan data dalam penelitian ini menggunakan regresi linear berganda. Prosesnya dilakukan beberapa tahapan analisis. Pada tahap yang pertama yaitu mencari hubungan antara variabel independen dan variabel dependen, adapun hasil perhitungannya akan ditampilkan dalam tabel 2, tabel 3, tabel 4, dan tabel 5. 
Tabel 2. Correlations

\begin{tabular}{clr}
\hline & & \multicolumn{1}{c}{ Y } \\
\hline X1 & Pearson Correlation & $.946^{* *}$ \\
& Sig. (2-tailed) & .000 \\
& $\mathrm{~N}$ & 23 \\
\hline X2 & Pearson Correlation & $.771^{* *}$ \\
& Sig. (2-tailed) & .000 \\
& $\mathrm{~N}$ & 35 \\
\hline **. Correlation is significant at the 0.01 level (2- \\
tailed).
\end{tabular}

Tabel 2 menunjukan korelasi antar variabel penelitian. Dari tabel di atas dapat disimpulkan bahwa kedua variabel bebas (Kepemimpinan Pembelajaran Kepala Sekolah (X1) dan Kompetensi Pedagogik Guru PAI) berkorelasi dengan Karakter Religius-Toleran Siswa Muslim, dengan korelasi terkuat adalah Kepemimpinan Pembelajaran Kepala Sekolah terhadap Karakter Religius-Toleran Siswa Muslim yaitu 0.946. Hal ini menjadi rujukan dimasukannya variabel Kepemimpinan Pembelajaran Kepala Sekolah sebagai variabel pertama pada perhitungan regresi.

Langkah perhitungan berikutnya yaitu menggunakan ANOVA satu arah, model perhitunganini digunakan untuk mengetahui apakah ada perbedaan yang signifikan antara 2 variabel, salah satunya untuk menganalisis data kontrol. Adapun hasil perhitungannya akan ditampilkan dalam tabel 3 .

Tabel 3. Analisis Varians Karakter Religius-Toleran

\begin{tabular}{llrrrrr}
\hline & Model & Sum of Squares & Df & Mean Square & F & \multicolumn{1}{c}{ Sig. } \\
\hline 1 & Regression & 2.948 & 2 & 1.474 & 186.276 & $.000^{\mathrm{a}}$ \\
& Residual & .158 & 20 & .008 & & \\
Total & 3.106 & 22 & & & \\
\hline
\end{tabular}

a. Predictors: (Constant), X2, X1

b. Dependent Variabel: Y

Tabel 3 menunjukan kontribusi kedua variabel dalam menjelaskan variasi skor intensi. Berdasarkan tabel di atas, dapat dilihat nilai signifikansi $\mathrm{F}$ adalah $0.000(<$ 0.05). Hal ini berarti bahwa model regresi ini layak untuk digunakan dalam memprediksi hubungan antara variabel bebas dengan variabel terikat.
Langkah perhitungan berikutnya yaitu menggunakan regresi berganda (multiple regression), model perhitungan ini digunakan untuk melihat pengaruh dan sumbangan dua variabel bebas terhadap variabel terikat. Adapun hasil regresi dapat dilihat pada tabel 4 . 
Tabel 4. Hasil Analisis Regresi

\begin{tabular}{|c|c|c|c|c|c|c|}
\hline & \multirow[t]{2}{*}{ Model } & \multicolumn{2}{|c|}{$\begin{array}{c}\text { Unstandardized } \\
\text { Coefficients }\end{array}$} & \multirow{2}{*}{$\begin{array}{c}\begin{array}{c}\text { Standardized } \\
\text { Coefficients }\end{array} \\
\text { Beta }\end{array}$} & \multirow[t]{2}{*}{$\mathrm{t}$} & \multirow[t]{2}{*}{ Sig. } \\
\hline & & B & Std. Error & & & \\
\hline \multirow[t]{3}{*}{1} & (Constant) & -.475 & .230 & & -2.066 & .050 \\
\hline & $\mathrm{X} 1$ & 1.842 & .167 & 1.549 & 11.006 & .000 \\
\hline & $\mathrm{X} 2$ & -.704 & .153 & -.646 & -4.589 & .000 \\
\hline
\end{tabular}

a. Dependent Variabel: $\mathrm{Y}$

Berdasarkan tabel di atas diketahui pengaruh langsung yang diberikan X1 terhadap Y adalah sebesar 1,594. Sedangkan pengaruh tidak langsung X1 melalui X2 terhadap $\mathrm{Y}$ adalah perkalian antara beta $\mathrm{X} 1$ terhadap $\mathrm{Y}$ dengan beta $\mathrm{X} 2$ terhadap Y, yaitu 1,594 x $646=1,001$. Berdasarkan hasil perhitungan di atas diketahui bahwa nilai pengaruh langsung antara variabel $\mathrm{X} 1$ terhadap $\mathrm{Y}$ lebih besar dari pada pengaruh variabel X1 melalui X2 terhadap $\mathrm{Y}$, hal ini dapat disimpulkan bahwa secara tidak langsung X1 melalui $\mathrm{X} 2$ tidak memiliki pengaruh yang signifikan terhadap Y

Langkah selanjutnya yaitu menentukan model regresi dalam penelitian ini. Variabel tergantung pada regresi ini adalah karakter religiustoleran(Y) sedangkan variabel bebasnya adalah Kepemimpinan pembelajaran (X1) dan Kompetensi Pedagogik Guru PAI (X2). Model regresi berdasarkan hasil analisis di atas adalah:

$$
\mathrm{Y}=\mathbf{0 , 4 7 5}+\mathbf{1 , 8 4 2} \mathrm{X} 1+\mathbf{0 , 7 0 4} \mathrm{X} 2+\mathrm{e}
$$

Tampak pada persamaan tersebut menunjukkan angka yang signifikan pada kedua variabel yang ada variabel materi yang diajarkan dan cara menyampaikan materi (X2). Adapun interpretasi dari persamaan tersebut adalah :

\section{1. $b 0=0,475$}

Nilai konstan ini menunjukkan bahwa apabila tidak ada variabel karakter religius-toleran yang tercermin pada Kepemimpinan pembelajaran (X1) dan Kompetensi Pedagogik Guru PAI (X2), maka karakter religius- toleran siswa muslim tetap sebesar 0,475 kali. Dalam arti karakter religius-toleran siswa muslim adalah sebesar 0,475atau $48 \%$ sebelum atau tanpa adanya variabel karakter religiustoleran yang tercermin pada Kepemimpinan pembelajaran (X1) dan Kompetensi Pedagogik Guru PAI (X2).

2. $b 1=1,842$

Nilai parameter atau koefisien regresi $b_{1}$ ini menunjukkan bahwa jika variabel Kepemimpinan pembelajaran meningkat 1 kali, maka karakter religius-toleran meningkat 1,842 kali atau dengan kata lain setiap peningkatan karakter religius-toleran dibutuhkan variabel kepemimpinan pembelajaran sebesar 1,842 dengan asumsi variabel bebas yang lain (x2) tetap.

3. $b 2=0,704$

Nilai parameter atau koefisien regresi $b_{2}$ ini menunjukkan bahwa setiap variabel Kompetensi Pedagogik Guru PAI meningkat 1 kali, maka karakter religius-toleran naik sebesar 0,704 kali atau dengan kata lain setiap peningkatan karakter religius-toleran dibutuhkan variabel Kompetensi 
Pedagogik Guru PAI sebesar 0,704 dengan asumsi variabel bebas yang lain tetap.

Tabel 5. Model Summary ${ }^{b}$

\begin{tabular}{|c|c|c|c|c|c|}
\hline Model & $\mathrm{R}$ & R Square & Adjusted R Square & $\begin{array}{l}\text { Std. Error of the } \\
\text { Estimate }\end{array}$ & Durbin-Watson \\
\hline 1 & $.974^{\mathrm{a}}$ & .949 & .944 & .089 & 1.448 \\
\hline
\end{tabular}

Setelah dilakukan pengujian model, maka langkah selanjutnya adalah dilakukan perhitungan korelasi untuk mengukur ketepatan garis regresi dalam menjelaskan variasi nilai variabel independen. Hasil analisis korelasi yang diperoleh dari output regresi diperoleh $\mathrm{R}^{2}=0,949$. Angka ini menunjukan bahwa variasi karakter religius-toleran dapat dijelaskan oleh persamaan regresi yang diperoleh dengan nilai sebesar $94,9 \%$ sedangkan sisanya $4,1 \%$ dipengaruhi oleh variabel lain diluar persamaaan model.

\section{PEMBAHASAN}

Berdasarkan pada analisis data di atas maka dilakukan beberapa pembahasan di bawah ini:

1. Pengaruh X1 terhadap $Y$ secara parsial Berdasarkan analisis hasil penelitian di atas dapat diketahui bahwa nilai signifikansi X1 terhadap Y adalah sebesar 0.00 hal disimpulkan bahwa variabel Kepemimpinan Pembelajaran kepala sekolah berpengaruh terhadap karakter religius-toleran siswa muslim, dengan pengaruh sebesar 1,842 .

Besarnya nilai ini membuktikan bahwa kepala sekolah SMKN 1 Sumbermanjing Wetan sudah mampu menerapkan model kepemimpinan pembelajran yang efektif hal ini terbukti dengan terlaksananya semua item indicator kepemimpinan pembelajran, yaitu: a) Kepala sekolah mensosialisasikan dan menanamkan isi dan makna visi sekolahnya dengan baik.; b) Kepala sekolah melibatkan para pemangku kepentingan dalam pengelolaan sekolah (manajemen partisipatif).; c) Kepala sekolah memberikan dukungan terhadap pembelajaran; d) Kepala sekolah melakukan pemantauan terhadap proses belajar mengajar sehingga memahami lebih mendalam dan menyadari apa yang sedang berlangsung didalam sekolah; e) Kepala sekolah berperan sebagai fasilitator sehingga dengan berbagai cara dia dapat mengetahui kesulitan pembelajaran dan dapat membantu guru dalam mengatasi kesulitan belajar tersebut. Efektifitas kepemimpinan pembelajaran ini berhasil mempengaruhi siswa untuk memiliki karakter religius-toleran dalam diri siswa muslim. Hal ini sesuai dengan theory of planned behavior yang menyatakan bahwa salah satu yang mempengaruhi perilaku seseorang adalah norma subjektif. Norma subjektif yaitu harapan/tekanan dari orang sekitar yang memiliki kekuasaan/pemangku kebijakan.

2. Pengaruh $\mathrm{X} 2$ terhadap Y secara parsial

Berdasarkan analisis hasil penelitian di atas dapat diketahui bahwa nilai 
signifikansi $\mathrm{X} 2$ terhadap $\mathrm{Y}$ adalah sebesar 0.00, hal disimpulkan bahwa variabel kompetensi pedagogik guru PAI berpengaruh terhadap karakter religius-toleran siswa muslim, dengan kuat pengaruh yaitu 0.771 . Kompetensi Pedagogik Guru PAI berhasil merubah karakter siswa. Dari yang belum memiliki karakter religius-toleran menjadi berkarakter religius toleran. Keberhasilan kompetensi Guru PAI dalam mempengaruhi karakter siswa, bisa jadi karena Guru PAI telah mampu memahami siswa secara mendalam, merancang pembelajaran dengan baik, termasuk memahami landasan pendidikan untuk kepentingan pembelajaran, melaksanakan pembelajaran, merancang dan melaksanakan evaluasi pembelajaran, dan mampu mengembangkan siswa untuk mengaktualisasikan berbagai potensi yang dimilikinya.

3. Pengaruh $X 1$ dan $X 2$ terhadap $Y$ secata simultan

Berdasarkan analisis hasil penelitian di atas dapat diketahui bahwa nilai signifikansi $\mathrm{F}$ adalah $0.000(<0.05)$ hal disimpulkan bahwa variabel kepemimpinan pembelajran dan variabel kompetensi pedagogik guru PAI berpengaruh terhadap karakter religius-toleran siswa muslim. Kepala sekolah dengan kebijakan dan wewenang yang dimilikinya bersinergi dengan kompetensi pedagogik yang dimiliki guru PAI mampu mempengaruhi pembentukan karakter religius toleran yang dimiliki siswa muslim di SMAN 1 Sumbermanjing Wetan.

4. Pengaruh X1 terhadap Y melalui X2 Berdasarkan analisis hasil penelitian di atas diketahui pengaruh langsung yang diberikan X1 terhadap Y adalah sebesar 1,594. Sedangkan pengaruh tidak langsung X1 melalui X2 terhadap Y adalah 1,001. Berdasarkan hasil perhitungan tersebut dapat disimpulkan bahwa nilai pengaruh langsung antara variabel X1 terhadap $\mathrm{Y}$ lebih besar dari pada pengaruh variabel X1 melalui X2 terhadap $\mathrm{Y}$, hal ini dapat disimpulkan bahwa secara tidak langsung X1 melalui X2 tidak memiliki pengaruh yang signifikan terhadap $Y$. ini berarti bahwa kepemimpinan pembelajaran kepala sekolah tidak tercermin secara langsung dalam kompetensi pedagogic yang dimiliki oleh guru PAI. Kompetensi pedagogik yang dimiliki guru PAI bisa jadi lebih dipengaruhi proses pendidikan yang sudah dilaluinya, dibandingkan dengan kepemimpinan pembelajaran yang dilakukan oleh kepala sekolah.

\section{SIMPULAN DAN SARAN}

\section{Simpulan}

Berdasarkan proses analisis dan pembahasan hasil penelitian yang telah dilakukan. Maka dapat disimpulkan beberapa hal di bawah ini, antara lain:

1. Secara parsial kepemimpinan pembelajaran kepala sekolah berpengaruh terhadap karakter religius-toleran siswa muslim,

2. Secara parsial kompetensi pedagogik guru PAI berpengaruh terhadap karakter religius-toleran siswa muslim,

3. Secara simultan kepemimpinan pembelajran dan variabel kompetensi pedagogik guru PAI berpengaruh terhadap karakter religius-toleran siswa muslim, dan

4. Secara tidak langsung variabel kepemimpinan pembelajaran tidak memiliki pengaruh terhadap karakter religius-toleran siswa muslim melalui variabel kompetensi pedagogik guru PAI. 


\section{Saran}

1. Kepala Sekolah secara terus menerus diharapkan mampu meningkatkan perannya dalam pembelajaran di sekolah. Karena kebijakan dan keterlibatan kepala sekolah menjadi yang paling menentukan terwujudnya karakter religius-toleran siswa muslim.

2. Guru PAI hendaknya terus meningkatkan kompetensi pedagogik yang dimilikinya dalam pembelajaran mata pelajaran Pendidikan Agama Islam . Kualitas pembelajaran dan pemahaman yang benar tentunya akan menjadi salah satu penyebab terwujud atau tidaknya karakter religius-toleran siswa.

\section{DAFTAR PUSTAKA}

Akhyak, 2005. Profil Pendidikan Sukses, Surabaya: Elkaf.

Blasé, Joseph., \& Blasé, Jo. 2000. Effective instructional leadership Teachers' perspectives on how principals promote teaching and learning in schools. Journal of Educational Administration. Armidale: 2000. Vol. 38, Iss. 2; pg. 13.

DOI:10.1108/09578230010320082

Danim, Sudarwan. 2010. Kepemimpinan Pendidikan; Jenius, Etika, Kepemimpinan

Bandung: Alfabeta. Perilaku

Dan Emosi.

Direktur Jenderal PMPTK. 2015. Kepemimpinan Pembelajaran, Materi Diklat Penguatan Kepala Sekolah. Jakarta: Direktur Jenderal PMPTK.

Glickman, Carl D. 2002. Leadership for Learning. Virginia USA. ASCD.
Kunandar. 2007. Guru Profesional : Implementasi Kurikulum Tingkat Satuan Pendidikan (KTSP) dan Sukses dalam Sertifikasi Guru. Jakarta : Rajagrafindo Persada.

Kusmintaro dan Burhanuddin. 1997.Kepemimpinan Pendidikan Bagi Kepala Sekolah. Jakarta: Depdikbud

Lunenburg, Fred C, \& Irby, Beverly J. 2006. The Principalship; Vision to action. Wadsworth, Cengange learning.

Mulyasa, E. 2007. Standar Kompetensi dan Sertifikasi Guru, Bandung: PT Rosda Karya

Rosyada, Dede. 2013. Paradigma Pendidikan Demokratis, Sebuah Model pelibatan Masyarakat dalam Pendidikan, jakarta: Prenada Media.

Sagala, Syaiful. 2010. Supervisi Pembelajaran dalam Profesi Pendidikan. Bandung: Alfabeta.

Sarimaya, Farida. 2008. Sertifikasi Guru. Bandung: CV. Yrama Widya

Sergiovanni, Thomas J, McCarthy, Martha M, Fowler, Frances C. 2009 Educational Governance and Adiminstration. USA, Pearson Education,Inc.

Sudjiono, Anas. 1995. Pengantar Statistik Pendidikan, Jakarta: Raja Grafindo Persada.

Suhardan, Dadan. 2010. Supervisi Professional; Layanan Dalam Meningkatkan Mutu Pembelajaran Di Era Otonomi Daerah. Bandung: Alfabeta. 